\title{
Local review of treatment of hand enchondroma (artificial bone substitute versus autologous bone graft) in a tertiary referral centre: 13 years' experience
}

\author{
YW Hung *, WS Ko, WH Liu, CS Chow, YY Kwok, Clara WY Wong, WL Tse, PC Ho
}

\section{A B S T R A C T}

Objective: To evaluate the treatment outcomes of enchondroma of the hand with artificial bone substitute versus autologous (iliac) bone graft.

Design: Historical cohort study.

Setting: Tertiary referral centre, Hong Kong.

Patients: A total of 24 patients with hand enchondroma from January 2001 to December 2013 who underwent operation at the Prince of Wales Hospital and Alice Ho Miu Ling Nethersole Hospital in Hong Kong were reviewed. Thorough curettage of the tumour was performed in all patients, followed by either autologous bone graft impaction under general anaesthesia in 13 patients, or artificial bone substitute in 11 patients (10 procedures were performed under local or regional anaesthesia and 1 was done under general anaesthesia). The functional outcomes and bone incorporation were measured by QuickDASH (shortened version of the Disabilities of the Arm, Shoulder and Hand questionnaire) scores and radiological appearance, respectively. The mean follow-up period was 59 months.

Results: There were eight men and 16 women, with a mean age of 40 years. Overall, 17 cases involved phalangeal bones and seven involved metacarpal bones. Among both groups of patients, most of the affected digits had good range of motion and function after surgery. One patient in each study group had patient in the artificial bone substitute group was suspected to have recurrence 8 years after operation. Among the autologous bone graft group, four patients had persistent donor site morbidity at the last follow-up. In all patients, radiographs showed satisfactory bone incorporation.

Conclusions: Artificial bone substitute is a safe and effective treatment option for hand enchondroma, with satisfactory functional and radiographic outcomes. Artificial bone substitute offers the additional benefits of enabling the procedure to be done under local anaesthesia on a day-case basis with minimal complications.

\section{Hong Kong Med J 2015;21:217-23}

DOI: 10.12809/hkmj144325

\footnotetext{
1,2 YW Hung *, FHKCOS, FHKAM (Orthopaedic Surgery)

${ }^{2}$ WS Ko, MB, ChB

WH Liu, MB, BS

1,2 CS Chow, FHKCOS, FHKAM (Orthopaedic Surgery)

YY Kwok, BNurs, RN

1,2 CWY Wong, FHKCOS, FHKAM (Orthopaedic Surgery)

1,2 WL Tse, FHKCOS, FHKAM (Orthopaedic Surgery)

1,2 PC Ho, FHKCOS, FHKAM (Orthopaedic Surgery)
}

\section{Department of Orthopaedics and Traumatology, Prince of Wales Hospital, Shatin, Hong Kong \\ Department of Orthopaedics and Traumatology, Alice Ho Miu Ling Nethersole Hospital, Tai Po, Hong Kong}

* Corresponding author: hungyukwah@yahoo.com.hk

\section{New knowledge added by this study \\ Curettage followed by artificial bone substitute is a safe and effective way to manage enchondroma in the hand. Implications for clinical practice or policy \\ - Using artificial bone substitute to replace classic autologous bone graft for managing enchondroma in the hand has several advantages: (a) reduced donor site morbidity; (b) significantly reduced surgical time; (c) comparable results to autologous bone graft in terms of clinical and radiological outcomes; and (d) enables the surgery to be performed under local or regional anaesthesia, thus, patients can be discharged on the same day as the surgery.}

\section{Introduction}

Enchondroma is one of the most common benign bone tumours of the hand. It originates from cartilage and is commonly located in the proximal metaphysis of the proximal phalanx. ${ }^{1}$ The tumour usually presents as an incidental finding or pathological fracture.

Despite being the most common bone tumour in the hand, standardised treatment protocols are lacking. ${ }^{1}$ Options vary from observation alone, curettage alone, and curettage with bone grafting (recently with artificial bone substitute). At the 


\section{手部內生軟骨瘤治療（人工骨移植或 自體骨移植 ）：一所提供第三層醫療轉介服務的 醫院的八年經驗回顧}

\author{
洪煜華、高慧珊、廖永康、周靜珊、郭欣欣、黃詠儀、 \\ 謝永廉、何百昌
}

目的：比較人工骨移植或自體骨（髂骨）移植治療手部內生軟骨瘤的 效果。

設計：歷史隊列研究。

安排：香港一所提供第三層醫療轉介服務的中心。

患者：2001年1月至2013年12月期間於香港威爾斯親王醫院和雅麗 氏何妙齡那打素醫院共24個手部內生軟骨瘤患者接受手術。所有患 者接受腫瘤徹底刮除術, 其中 13 例在全身麻醉下接受自體骨移植, 另 11 例進行人工骨移植（局部或區域麻醉 10 例, 另全身麻醉 1 例 )。 通過手臂肩殘疾問卷表短期版本 (QuickDASH) 和影像學分別評估患 者的手部功能和癒合程度。平均隨訪時間為59個月。

結果：患者平均年齡 40 歲, 共8男16女。腫瘤部位方面, 指骨 17 例, 掌骨7例。術後大多數患者的手指總主動活動度和功能良好。兩組各 有一名患者出現局部軟組織炎症的併發症。接受人工骨移植的其中一 名患者術後 8 年懷疑有復發。接受自體骨移植的其中四名患者在最後 隨訪中發現供骨區有併發。所有患者的影像學結果均顯示植骨融合良 好。

結論：人工骨移植是手部內生軟骨瘤一種安全、有效的治療方案, 患 者術後的手指功能和影像學結果均令人滿意。人工骨移植能在門診局 部麻醉下進行, 無明顯併發症, 為患者帶來額外好處。
Prince of Wales Hospital (PWH), we used to treat enchondroma of the hand by complete curettage and filling the defect with autologous bone graft. Although autologous bone graft provides both biological and mechanical advantages in managing the bone void, this procedure is not without risk. Patients must undergo general anaesthesia to obtain the bone graft from the iliac crest, and most patients have considerable postoperative pain, which limits their walking ability for a variable period.

Recently, studies evaluating the clinical application of artificial bone substitute have shown promising results. ${ }^{2,3}$ However, this is a relatively new technique in local practice. In a cohort study, we retrospectively analysed the treatment outcomes of patients with hand enchondroma and compared the results for autologous bone graft and artificial bone substitute.

\section{Methods}

From January 2001 to December 2013, all patients with symptomatic monostotic enchondroma of the phalanges or metacarpals treated at the PWH or the Alice Ho Miu Ling Nethersole Hospital (AHNH) underwent thorough curettage according to the standard protocol. The bone defects were filled by either autologous bone graft or artificial bone substitute, depending on the surgeon's and patient's preferences. All operations were done by the same team of orthopaedic specialists. For patients presenting with pathological fracture, the fracture was first managed conservatively until healed. The

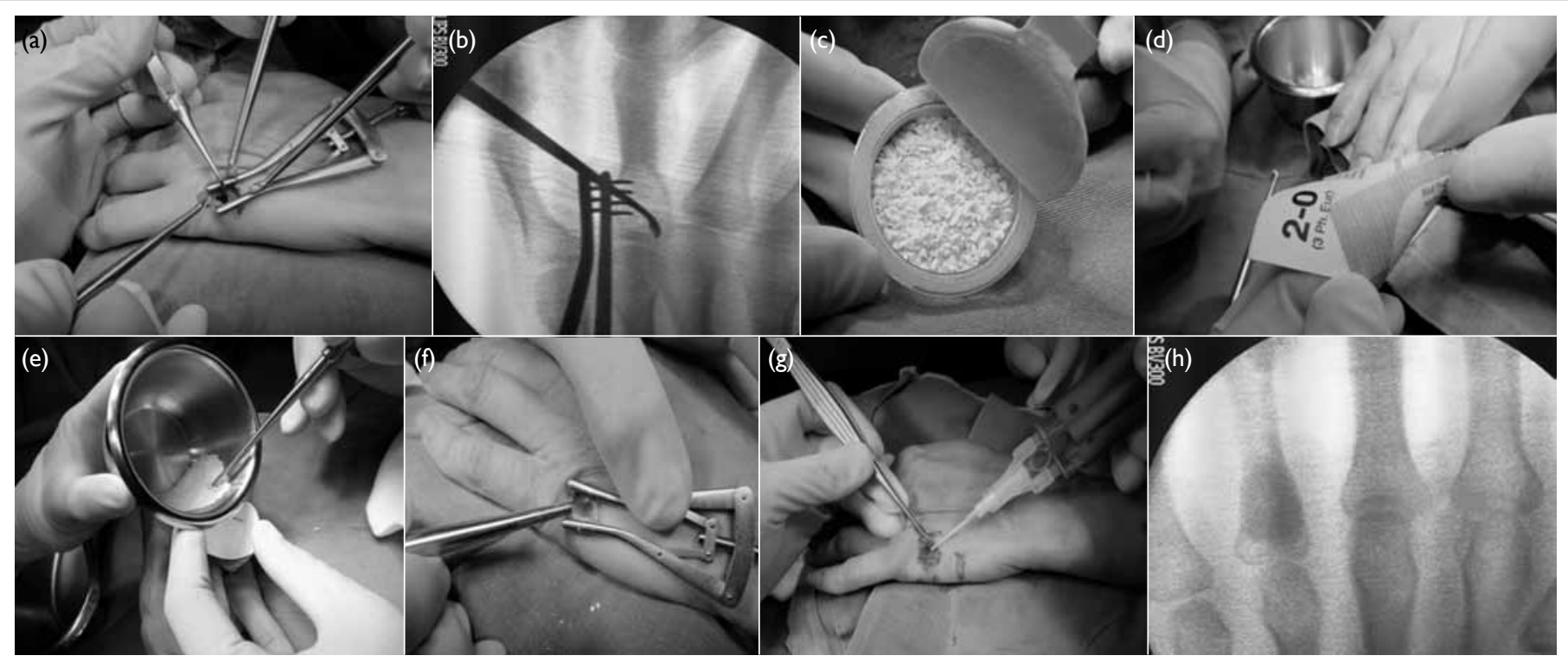

FIG. Surgical technique for removal of enchondroma and bone graft repair

(a) Removal of the tumour and (b) clearance checked by fluoroscopy, (c) the cavity filled and impacted tightly with artificial bone substitute, (d and e) insertion of the bone substitute via a funnel, (f) the bone substitute granules impacted tightly by using a punch, (g) the cortical window is sealed off with fibrin glue to prevent spillage of bone substitute, and (h) tightly packed bone substitute into cavity was confirmed by fluoroscopy 
surgery for the tumour was performed 3 months after initial presentation.

\section{Surgical technique}

In the artificial bone substitute group, an incision was centred on the lesion, and the extensor tendon was retracted, with no subperiosteal dissection. A small oval cortical window was made by connecting multiple drill hole perforations prepared by a 0.9-mm Kirschner wire. The tumour was removed by small-angle curettage and clearance was checked under fluoroscopic control (Figs a and b). The cavity was then filled with artificial bone substitute (Fig c).

A custom-made paper funnel was used for precise insertion of bone substitute to avoid spillage to the surrounding soft tissue, which could be difficult to remove (Figs $d$ and e). Bone substitute granules were impacted tightly by using a punch (Fig f). The piece of oval cortical bone was placed back in position, and the periosteum was repaired where possible; alternatively, the window was sealed with fibrin glue (Tisseel; Baxter Healthcare Corp, Deerfield [IL], US) to contain the bone substitute (Fig g). The wound was closed with fine nylon suture. A radiograph was taken to confirm filling of the defect and absence of fracture (Fig h). Free mobilisation was allowed postoperatively.

In the autologous bone graft group, the operation was done under general anaesthesia. The surgical approach and procedures to the affected bone were the same as for the artificial bone substitute group, except that autologous cancellous bone grafts harvested from iliac crest were used instead of artificial bone substitute. We do not usually obtain the bone graft from the ipsilateral distal radius as the quantity is insufficient for packing the wound. Free mobilisation was allowed postoperatively.

\section{Statistical analysis}

The operative details and postoperative clinical and radiological outcomes were reviewed by an independent reviewer. Fisher's exact test was

TABLE I. Demographic data of patients with enchondroma

\begin{tabular}{|c|c|c|c|c|c|c|c|c|c|}
\hline $\begin{array}{l}\text { Patient } \\
\text { No. }\end{array}$ & Sex & $\begin{array}{c}\text { Age } \\
\text { (years) }\end{array}$ & Side & Location & Size (mm) & $\begin{array}{c}\text { Takigawa } \\
\text { classification }\end{array}$ & Presentation & $\begin{array}{c}\text { Bone } \\
\text { substitute used }\end{array}$ & $\begin{array}{c}\text { FU period } \\
\text { (months) }\end{array}$ \\
\hline \multicolumn{10}{|c|}{ Artificial bone substitute group } \\
\hline 1 & $\mathrm{~F}$ & 53 & Left & 2nd PP & $13.5 \times 7$ & Central & Incidental finding & Bio-1 & 12 \\
\hline 2 & $\mathrm{~F}$ & 47 & Left & 5th $\mathrm{MC}$ & $13 \times 11$ & Central & Pain & Bio-1 & 14 \\
\hline 3 & $\mathrm{~F}$ & 45 & Left & 5th MP & $9 \times 4$ & Central & Fracture & Bio-1 & 13 \\
\hline 4 & $F$ & 44 & Left & 5th PP & $13 \times 11$ & Central & Fracture & Bio-1 & 15 \\
\hline 5 & $\mathrm{~F}$ & 33 & Left & 4th PP & $8 \times 13$ & Central & Fracture & Bio-1 & 20 \\
\hline 6 & M & 43 & Right & 2nd MC & $15 \times 10$ & Peripheral & Pain, swelling & Bio-1 & 153 \\
\hline 7 & $\mathrm{~F}$ & 48 & Left & 5th PP & $14 \times 65$ & Central & Fracture & Bio-1 & 32 \\
\hline 8 & M & 52 & Left & 2nd PP & N/A & Central & Fracture & Bio-1 & 104 \\
\hline 9 & $\mathrm{~F}$ & 27 & Left & 5th MC & $23 \times 7$ & Central & Pain, swelling & Bio-1 & 104 \\
\hline 10 & $\mathrm{~F}$ & 53 & Left & 3rd MC & $20 \times 16$ & Central & Pain, swelling & Norian & 32 \\
\hline 11 & $\mathrm{~F}$ & 56 & Right & 2nd MC & $20 \times 20$ & Central & Swelling & Bio-1 & 153 \\
\hline \multicolumn{10}{|c|}{ Autologous bone graft group } \\
\hline 12 & $\mathrm{~F}$ & 26 & Left & 2nd PP & $15 \times 11$ & Central & Fracture & - & 41 \\
\hline 13 & $\mathrm{~F}$ & 41 & Left & 2nd PP & $13 \times 13$ & Central & Pain & - & 37 \\
\hline 14 & $\mathrm{~F}$ & 46 & Left & 5th PP & $11 \times 12$ & Central & Fracture & - & 36 \\
\hline 15 & $F$ & 49 & Left & 5th PP & $12 \times 5$ & Central & Fracture & - & 17 \\
\hline 16 & M & 30 & Left & 5th PP & $11 \times 10$ & Central & Pain & - & 16 \\
\hline 17 & M & 57 & Left & 3rd PP & $6 \times 7$ & Peripheral & Pain, swelling & - & 4 \\
\hline 18 & M & 34 & Left & 1st DP & $10 \times 13$ & Central & Fracture & - & 102 \\
\hline 19 & M & 48 & Right & 2nd PP & $12 \times 14$ & Central & Pain & - & 98 \\
\hline 20 & $\mathrm{~F}$ & 25 & Left & 5th MC & $9 \times 24$ & Central & Pain, swelling & - & 94 \\
\hline 21 & M & 25 & Right & 4th PP & $12 \times 11$ & Central & Fracture & - & 90 \\
\hline 22 & M & 27 & Right & 4th PP & $10 \times 27$ & Central & Pain & - & 88 \\
\hline 23 & $\mathrm{~F}$ & 36 & Right & 2nd MC & $12 \times 14$ & Central & Pain & - & 88 \\
\hline 24 & $\mathrm{~F}$ & 23 & Right & 3rd PP & $20 \times 20$ & Central & Pain & - & 65 \\
\hline
\end{tabular}

Abbreviations: DP = distal phalanx; FU = follow-up; $M C$ = metacarpal; $M P$ = middle phalanx; $\mathrm{N} / \mathrm{A}$ = not available; $\mathrm{PP}=$ proximal phalanx 
TABLE 2. Summary of data for each treatment group

\begin{tabular}{|c|c|c|c|}
\hline & $\begin{array}{c}\text { Autologous bone graft } \\
\text { group }(n=13)\end{array}$ & $\begin{array}{l}\text { Artificial bone substitute } \\
\text { group }(n=11)\end{array}$ & $P$ value \\
\hline Male:female & $6: 7$ & $2: 9$ & 0.211 \\
\hline Mean (range) age (years) & $35(23-57)$ & $45(27-56)$ & 0.03 \\
\hline Site (phalanx:metacarpal) & $11: 2$ & $6: 5$ & 0.082 \\
\hline Mean size $\left(\mathrm{mm}^{2}\right)$ & 166 & 164 & 0.96 \\
\hline No. of patients with fracture at presentation & 5 & 5 & - \\
\hline Mean (range) follow-up (months) & $59(4-102)$ & $59(12-153)$ & 0.98 \\
\hline
\end{tabular}

TABLE 3. Comparison of operative data

\begin{tabular}{|c|c|c|c|}
\hline $\begin{array}{l}\text { Patient } \\
\text { No. }\end{array}$ & Mode of anaesthesia & Operating time (mins) & Additional procedure \\
\hline \multicolumn{4}{|c|}{ Artificial bone substitute group } \\
\hline 1 & IVLA & 80 & Nil \\
\hline 2 & IVLA & 71 & Nil \\
\hline 3 & IVLA & 77 & Nil \\
\hline 4 & IVLA & 65 & Nil \\
\hline 5 & IVLA & 115 & Nil \\
\hline 6 & IVLA & 85 & Nil \\
\hline 7 & IVLA & 60 & Nil \\
\hline 8 & IVLA & 68 & Nil \\
\hline 9 & RPB & 64 & Nil \\
\hline 10 & GA & 135 & Frozen section \\
\hline 11 & IVLA & 80 & Nil \\
\hline Mean & & 81 & \\
\hline \multicolumn{4}{|c|}{ Autologous bone graft group } \\
\hline 12 & GA & 118 & Nil \\
\hline 13 & GA & 100 & Nil \\
\hline 14 & GA & 90 & Nil \\
\hline 15 & GA & 120 & Nil \\
\hline 16 & GA & 111 & Nil \\
\hline 17 & GA & 90 & Nil \\
\hline 18 & $\mathrm{GA}$ & 120 & Nil \\
\hline 19 & GA & 120 & Nil \\
\hline 20 & GA & 90 & Nil \\
\hline 21 & GA & 150 & Plate insertion \\
\hline 22 & GA & 90 & Nil \\
\hline 23 & $\mathrm{GA}$ & 120 & Nil \\
\hline 24 & GA & 60 & Nil \\
\hline Mean & & 106 & \\
\hline
\end{tabular}

Abbreviations: GA = general anaesthesia; IVLA = intravenous local anaesthesia; RPB = regional plexus block function measured by the Chinese and shortened version of the DASH (QuickDASH) ${ }^{4}$ were evaluated. Plain radiographs were taken at standard intervals $(1$ week, 4 weeks, 3 months, 6 months, and annually) postoperatively to determine bone incorporation. Bone incorporation was defined as a seamless appearance with no gap between the cancellous bone and the bone substitute. For any suspicious symptoms or radiographic appearance, computed tomography or magnetic resonance imaging (MRI) was performed to look for any recurrence.

\section{Results}

There were 24 patients (eight men and 16 women), with a mean age of 40 years. Overall, 17 cases involved the phalangeal bones and seven involved the metacarpal bones; 13 patients underwent autologous bone graft and 11 had artificial bone substitute. Five patients in each group presented with pathological fracture, among whom nine were managed conservatively until the fracture was healed. Patients' demographics, including site and size of the tumour, presentation, and time to operation are shown in Tables $1^{5}$ and 2 . In all patients, the histology confirmed the diagnosis of enchondroma. The operative details and postoperative outcomes are shown in Tables 3 to 5 .

For the artificial bone substitute group, 10 of 11 patients were operated on using intravenous local anaesthesia or regional plexus block. One patient was operated on under general anaesthesia as the MRI showed suspicion for malignancy, and frozen section was performed during the operation. The mean surgical time was 81 minutes (range, 60-135 minutes). All surgeons used Bio-1 granules (SBM France, Lourdes, France) except for one patient for whom injectable bone substitute (Norian SRS; Synthes USA, Paoli [PA], US) was used because of the surgeon's preference.

For the autologous bone graft group, all 13 patients were operated on under general anaesthesia. The mean surgical time was 106 minutes (range, 60-150 minutes), which was 25 minutes longer than for the artificial bone substitute group $(\mathrm{P}=0.008)$.

The mean follow-up period was 59 months 
TABLE 4. Results for patients treated with curettage and artificial bone substitute or autologous bone graft

\begin{tabular}{|c|c|c|c|c|c|c|}
\hline $\begin{array}{l}\text { Patient } \\
\text { No. }\end{array}$ & Symptom & Range of motion & $\begin{array}{l}\text { QuickDASH } \\
\text { score }\end{array}$ & Radiograph & Complication & $\begin{array}{l}\text { Donor site } \\
\text { morbidity } \\
\text { at latest } \\
\text { assessment }\end{array}$ \\
\hline \multicolumn{7}{|c|}{ Artificial bone substitute group } \\
\hline 1 & Residual wound swelling & Full & 2.3 & Bone incorporation & $\begin{array}{l}\text { Postoperative soft } \\
\text { tissue inflammation } \\
\text { (needed debridement) }\end{array}$ & - \\
\hline 2 & Asymptomatic & Full & 2.3 & Bone incorporation & Nil & - \\
\hline 3 & Pain on maximal flexion & Full & 2.3 & Bone incorporation & Nil & - \\
\hline 4 & Asymptomatic & Full & 2.3 & Bone incorporation & Nil & - \\
\hline 5 & Asymptomatic & Full & 2.3 & Bone incorporation & Nil & - \\
\hline 6 & Asymptomatic & Full & 2.3 & Bone incorporation & Nil & - \\
\hline 7 & Asymptomatic & $25^{\circ}$ Extension lag of PIPJ & 2.3 & Bone incorporation & Nil & - \\
\hline 8 & Asymptomatic & Full & 2.3 & Bone incorporation & Nil & - \\
\hline 9 & Asymptomatic & Full & 2.3 & Bone incorporation & Distal recurrence & - \\
\hline 10 & Asymptomatic & Full & 2.3 & Bone incorporation & Nil & - \\
\hline 11 & Asymptomatic & Full & 2.3 & Bone incorporation & Nil & - \\
\hline \multicolumn{7}{|c|}{ Autologous bone graft group } \\
\hline 12 & Asymptomatic & Full & 0 & Bone incorporation & Nil & Mild numbness \\
\hline 13 & Asymptomatic & Full & 0 & Bone incorporation & Nil & Nil \\
\hline 14 & Pain in end range and stiffness & Stiffness (MCPJ 0-50) & 2.3 & Bone incorporation & Nil & Nil \\
\hline 15 & Pain in end range and stiffness & 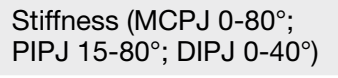 & 2.3 & Bone incorporation & Nil & Mild numbness \\
\hline 16 & Asymptomatic & Full & 0 & Bone incorporation & Nil & Nil \\
\hline 17 & Asymptomatic & Full & 0 & Bone incorporation & Nil & Nil \\
\hline 18 & Asymptomatic & Full & 5.3 & Bone incorporation & Nil & Nil \\
\hline 19 & Asymptomatic & Full & 0 & Bone incorporation & Nil & Nil \\
\hline 20 & Asymptomatic & Full & 0 & Bone incorporation & Nil & Nil \\
\hline 21 & Pain and stiffness & 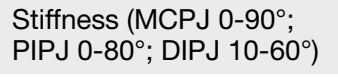 & 41.6 & Bone incorporation & $\begin{array}{l}\text { Postoperative soft } \\
\text { tissue inflammation }\end{array}$ & $\begin{array}{l}\text { Pain (VAS score } \\
4 / 10)\end{array}$ \\
\hline 22 & Asymptomatic & Full & $N / A^{*}$ & Bone incorporation & Nil & Nil \\
\hline 23 & Asymptomatic & Full & 0 & Bone incorporation & Nil & Nil \\
\hline 24 & Residual pain & Full & 10 & Bone incorporation & Nil & Mild numbness \\
\hline
\end{tabular}

Abbreviations: DIPJ = distal interphalangeal joint; $\mathrm{MCPJ}=$ metacarpophalangeal joint; $\mathrm{N} / \mathrm{A}=$ not available; PIPJ = proximal interphalangeal joint; QuickDASH = shortened version of the Disabilities of the Arm, Shoulder and Hand questionnaire; VAS = visual analogue scale

* Lost to follow-up

TABLE 5. Summary of outcomes for each group

\begin{tabular}{lccc}
\hline & Autologous bone graft group $(\mathbf{n}=\mathbf{1 3})$ & Artificial bone substitute group ( $\mathbf{n = 1 1 )}$ & P value \\
\hline Pain:painless (finger) & $4: 9$ & $2: 9$ & 0.649 \\
QuickDASH score & 5.1 & 2.3 & 0.128 \\
Radiological & All bone incorporation & All bone incorporation & - \\
Complication & 1 Low-grade superficial infection & 1 Foreign body reaction & - \\
Donor site & 4 Residual pain or numbness & 1 Proximal recurrence & - \\
\hline
\end{tabular}

Abbreviation: QuickDASH = shortened version of the Disabilities of the Arm, Shoulder and Hand questionnaire 
(mean 59 months, range 4-102 months in the autologous bone graft group and mean 59 months, range 12-153 months in the artificial bone substitute group). All patients demonstrated satisfactory bone incorporation. There were no significant observable radiological differences between the groups 1 year after operation. Functional recovery was similar in both groups. There were no significant differences in QuickDASH scores (mean 2.3 for artificial bone substitute group and 5.1 for autologous bone graft group; $\mathrm{P}=0.128)$.

\section{Complications}

One patient in each group developed soft tissue complications 3 weeks after the operation. The patient in autologous bone graft group presented with erythema over the surgical site. The condition improved after intravenous antibiotic treatment was given and the patient was diagnosed to have a low-grade superficial infection. The patient in the artificial bone substitute group presented with discharge from the wound and radiograph showed a trace amount of tiny calcifications in the soft tissue adjacent to the affected digit. The culture swab of the discharge fluid showed negative growth. The patient was treated with empirical antibiotics and surgical debridement showed a small amount of bone substitute in the subcutaneous plane of the wound. The diagnosis was probable inflammation secondary to foreign body reaction, rather than a genuine infection. Both patients had satisfactory wound healing and bone healing.

Recurrence of enchondroma was suspected in one patient in the artificial bone substitute group. The patient had a radiolucent lesion at the proximal part of the affected metacarpal on plain radiograph during routine follow-up 8 years after the index operation. The patient subsequently underwent a second operation to remove the lesion.

\section{Discussion}

Joosten et $\mathrm{al}^{2}$ first reported treatment of enchondroma with artificial bone substitute in 2000. Eight patients were treated with hydroxyapatite cement to fill the bone cavity. All of the patients gained full function of the hand and no complications were observed during 1-year follow-up. Subsequently, studies from Japan $^{3}$ and South Korea ${ }^{6}$ have also shown satisfactory outcomes using calcium bone cement and calciumbased pellets, respectively.

At the PWH and $\mathrm{AHNH}$, we treat all hand enchondromas surgically because the tumour will usually grow, weaken the bone, and result in pathological fracture. Since the bone will be further weakened by curettage alone, we believe that replacement with an osteogenic or osteoconductive substance will facilitate bone healing and remodelling so that this fracture-prone period can be shortened. We traditionally treated hand enchondroma with curettage and filled the defect with autologous bone graft. However, we started treating with artificial bone substitute in 2001. In 2010, we changed to routine use of autologous bone graft because there are several advantages of reduced donor site morbidity, use of local anaesthesia, reduced operating time (mean, 25 minutes less), and the surgery can be performed on a day-case basis.

There are different types of bone substitute available in the market. In this study, either Bio-1 granules or injectable Norian ${ }^{7}$ was used. These bone substitutes are synthetic materials made with resorbable calcium phosphate. The composition comprises calcium and phosphate ions, which are biocompatible with natural bone minerals. ${ }^{8}$ An invitro study shows that calcium phosphate allows osteoblast fixation and proliferation, ${ }^{8}$ followed by osteointegration and bone resorption mimicking normal bone healing. Calcium phosphate is available in granules or cubes and in an injectable form.

In this study, complete curettage of the tumour was achieved, with histological confirmation of the diagnosis. There were no significant differences in QuickDASH scores between the two groups.

Autologous bone graft takes around 4 to 6 months to incorporate while, for artificial bone substitute, the time to incorporation depends on the type of bone substitute used. Bio-1 takes approximately 9 to 12 months to incorporate. There were no significant radiological differences between the groups at 1 year postoperatively. Norian stays in the bone for longer than Bio-1 and is not completely resorbed up to 3 years postoperatively.

The mean follow-up period of this study was 59 months, which is longer than in most studies. The numbers of patients in each treatment group were comparable with other studies. We observed suspected recurrence in the affected metacarpal in one patient, who had undergone operation 8 years previously. A radiolucent lesion was noted beneath the bone substitute. We postulated that there might have been residual enchondroma cells seeding at the base of the lesion after curettage, which were displaced proximally during impaction of the bone substitute.

There were several limitations to this study. First, there was a difference in patient age between the two groups, which is a confounding variable. This might be accounted for by the relatively low incidence of enchondroma despite it being the most common upper limb tumour. Second, the choice of artificial bone substitute was not standardised, as two different substitutes were used. Norian SRS injectable bone substitute was used in one patient and Bio-1 was used in the other patients. Third, radiological assessment postoperatively might not be 
accurate. Despite all radiographs being reviewed by experienced orthopaedic specialists, the diagnosis of bone incorporation was subjective, with the chance for inter- and intra-observer bias. Finally, this study was retrospective and non-randomised.

\section{Conclusions}

Overall, most patients gained full range of motion and satisfactory function, with radiological evidence of bone incorporation and, later, bone growth. The application of artificial bone substitute gives comparable functional and radiological results in treating enchondroma of the hand. The procedure allows reduction in operating time, elimination of donor site morbidity, and day-case surgery under local or regional anaesthesia. Meticulous curettage and bone substitute impaction without spillage to the surrounding soft tissues are key to achieving good outcomes and avoiding complications.

\section{References}

1. Sassoon AA, Fitz-Gibbon PD, Harmsen WS, Moran SL.
Enchondromas of hand: factors affecting recurrence, healing, motion, and malignant transformation. J Hand Surg Am 2012;37:1229-34.

2. Joosten U, Joist A, Frebel T, Walter M, Langer M. The use of in situ curing hydroxyapatite cement as an alternative of bone graft following removal of enchondroma of the hand. J Hand Surg Br 2000;25:288-91.

3. Yasuda M, Masada K, Takeuchi E. Treatment of enchondroma of the hand with injectable calcium phosphate bone cement. J Hand Surg Am 2006;31:98-102.

4. Lee EW. Chinese QuickDASH (PWH, HK version). Physiotherapy Department, Prince of Wales Hospital. Toronto: Institute for Work and Health; 2006.

5. Takigawa K. Chondroma of the bones of the hand. A review of 110 cases. J Bone Joint Surg Am 1971;53:1591-600.

6. Choy WS, Kim KJ, Lee SK, Yang DS, Park HJ. Treatment for hand enchondroma with curettage and calcium sulfate pellet (OsteoSet ${ }^{\circledR}$ ) grafting. Eur J Orthop Surg Traumatol 2012;22:295-9.

7. Hak DJ. The use of osteoconductive bone graft substitutes in orthopaedic trauma. J Am Acad Orthop Surg 2007;15:52536.

8. Le Huec JC, Clément D, Lesprit E, Faber J. The use of calcium phosphate, their biological properties. Eur J Orthop Surg Traumatol 2000;10:223-9. 